\title{
Species specific plant-soil interactions influence plant distribution on serpentine soils
}

\author{
Brynne E. Lazarus • James H. Richards • \\ Victor P. Claassen • Ryan E. O'Dell • \\ Molly A. Ferrell
}

Received: 4 October 2010 / Accepted: 16 December 2010/Published online: 26 January 2011

(C) The Author(s) 2011. This article is published with open access at Springerlink.com

\begin{abstract}
Where serpentine soils exist, variation in soil properties affects plant species distribution at both coarse and fine spatial scales. The New Idria (California, USA) serpentine mass has barren areas, supporting only sparse shrub and tree islands, adjacent to areas of densely-vegetated serpentine chaparral. To identify factors limiting growth on barren relative to vegetated serpentine soils, we analyzed soils from barren, shrub-island within barren, and vegetated areas and foliage from shrubisland and vegetated areas. We also grew Ceanothus cuneatus (native evergreen shrub), Achillea millefo-
\end{abstract}

Responsible Editor: Juan Barcelo.

Electronic supplementary material The online version of this article (doi:10.1007/s11104-010-0698-2) contains

supplementary material, which is available to authorized users.

B. E. Lazarus $(\bowtie) \cdot J$. H. Richards $\cdot$ V. P. Claassen

Department of Land, Air \& Water Resources,

University of California Davis,

One Shields Ave,

Davis, CA 95616-8627, USA

e-mail: belazarus@ucdavis.edu

\section{R. E. O'Dell}

United States Bureau of Land Management

Hollister Field Office,

20 Hamilton $\mathrm{Ct}$.,

Hollister, CA 95023, USA

M. A. Ferrell

Cache Creek Conservancy,

P.O. Box 8249, Woodland, CA 95776-8249, USA lium (native perennial forb), and Bromus madritensis ssp. rubens (invasive annual grass) in soils from barren and vegetated areas amended factorially with $\mathrm{N}, \mathrm{K}$, and $\mathrm{Ca}$ in a pot study. In well-watered pots, biomass was greater by 5-, 14-, and 33-fold for Ceanothus, Achillea, and Bromus, respectively, on vegetated-area-collected soils than on barren-collected soils, indicating a strong soil chemistry effect. Although field soil data suggested nutrient deficiency and not heavy metal toxicity, pot study plant data indicated otherwise for two of the three species. On barren-collected soils, only Ceanothus responded positively to added $\mathrm{N}$ and $\mathrm{Ca}$ and did not show greater foliar $\mathrm{Mg}$ or heavy metal (Fe, Ni, $\mathrm{Cr}, \mathrm{Co}, \mathrm{Zn}$ ) concentrations than on vegetated-area-collected soils. Ceanothus maintained lower root $\mathrm{Mg}$ and heavy metal ( $\mathrm{Fe}, \mathrm{Ni}, \mathrm{Cr}, \mathrm{Co}$ ) concentrations on barren soils and translocated less heavy metal (Fe, Ni, Cr, Co, Mn, $\mathrm{Cu}$ ) from roots to foliage than Achillea and Bromus. Achillea and Bromus showed significant log-log biomass relationships with foliar $\mathrm{Ca}: \mathrm{Mg}(+), \mathrm{Mg}(-)$, and heavy metals (Fe, Ni, Cr, Co, Mn, Cu, Zn) (-), while Ceanothus showed relationships only with $\mathrm{Ca}$ : $\mathrm{Mg}(+)$ and $\mathrm{Mg}(-)$. The New Idria barren-vegetated pattern appears to be maintained by different factors for different species or functional types - low Ca:Mg ratios on barrens for all species tested, high heavy metal concentrations for Achillea and Bromus, and low macronutrient $(\mathrm{N})$ concentrations for Ceanothus. Combined data from this and other studies suggest high heavy metal concentrations more strongly affect 
herbaceous than woody species, contributing to variation in species distribution on serpentine soils.

Keywords Ultramafic soils · Low nutrient adaptation · Calcium:magnesium ratio $\cdot$ Metal toxicity $\cdot$ Nickel

\section{Introduction}

Much variation exists among soils derived from ultramafic parent materials, generally (and hereafter) referred to as serpentine soils. At global and regional scales, different temperature and precipitation regimes lead to different weathering and leaching rates as well as various serpentine plant communities that differentially influence soil properties (e.g., forests and grassland create different types and spatial distributions of soil organic matter). Topographic differences create variation at a local scale (Rajakaruna and Bohm 1999; Alexander et al. 2007). At multiple scales, differences in parent material (e.g., degree of serpentinization, mineral composition, presence of accessory minerals) influence soil chemistry, erosion resistance, and weathering rates (Alexander et al. 2007; McGahan et al. 2008, 2009). The New Idria serpentine mass (San Benito and Fresno Counties, California, USA) shows striking within-site variation, with dense chaparral giving way to barrens that are nearly devoid of vegetation except for scattered shrub and tree islands. Though some of California's broad scale serpentine vegetation patterns are well understood (e.g., the distribution of forest vs. grassland corresponds with precipitation), other differences (such as the distribution of grassland vs. chaparral) are not yet clear (Grace et al. 2007), and there has been little study of what causes barrens, though hypotheses include lack of soil formation resulting from geologic and topographic instability (Coleman 1996; Kruckeberg 1999).

It is also clear that plant species respond differently to serpentine soils, with some excluded altogether, others "indifferent" (bodenvag), and still others endemic (found only on serpentine soils) (Kruckeberg 1984; Safford et al. 2005). Many bodenvag species have serpentine edaphic ecotypes that perform better on serpentine soils than nonserpentine ecotypes (Kruckeberg 1951; O’Dell and Claassen 2006; O’Dell and Rajakaruna 2011). Different species growing together on the same soils often have different foliar elemental concentrations, indicating different nutrient selectivities (Lyon et al. 1971; Johnston and Proctor 1977; Koenigs et al. 1982; Alexander et al. 1989; Pope et al. 2010). Different chemical elements may limit different species on serpentine, resulting in species-specific responses to substrate amendments (e.g., Koide and Mooney 1987; Huenneke et al. 1990; Nagy and Proctor 1997).

Plant ecologists and evolutionary biologists have long been fascinated by the common attribute of serpentine soils - uniquely adapted and often endemic plant species and communities that differ markedly from those of adjacent, non-serpentine soils as a result of the relative "infertility" of serpentine soil. This infertility is commonly attributed to a "syndrome" of chemical and physical features - low macronutrient content, low calcium $(\mathrm{Ca})$ to magnesium $(\mathrm{Mg})$ molar ratios, high heavy metal content, micronutrient deficiency, and poor water-holding properties (Proctor and Woodell 1975). While experimental evidence supports the role of each factor of the serpentine syndrome in causing serpentine infertility in one case or another, no single factor has emerged as growthlimiting in every instance, and few studies have simultaneously considered more than one facet of the serpentine syndrome for more than one species or functional type or on more than one serpentine soil. The most logical explanation for differing results is that the factors of greatest importance causing serpentine infertility vary not only from one serpentine soil to another, but also from one plant species or functional group to another.

In this study, we considered multiple hypotheses of serpentine infertility (macronutrients nitrogen $(\mathrm{N})$ and potassium (K), low $\mathrm{Ca}: \mathrm{Mg}$ molar ratios, and high heavy metal concentrations) for multiple species. Our objective was to better understand the New Idria barrenvegetated pattern and whether it varied with species. We hypothesized that this pattern is maintained by differences in soil chemical and/or fine scale physical properties that limit plant growth on barren relative to vegetated soils. To test this hypothesis we 1) analyzed field collected samples of soils and foliage and 2) conducted an experimental study with three serpentinecollected species representing three plant functional groups (native evergreen shrub, native perennial forb, and invasive annual grass) grown in soils collected from barren and vegetated areas amended with factorial nutrient combinations $(\mathrm{N}, \mathrm{K}, \mathrm{Ca})$. 
Sub-hypotheses and the data that addressed each were as follows:

1) Plant growth is limited on barren relative to vegetated soils by fine scale soil physical properties. This was tested by comparing texture and water holding properties on field-collected barren, shrub-island within barren, and vegetated soils. Significant differences among soil types would indicate possible limitation by physical factors.

2) Plant growth is limited on barren relative to vegetated soils by soil chemical properties. This was tested by comparisons of plant growth on both soil types in well-watered pots, which eliminated possible physical limitations. Significant differences obtained under these conditions would indicate the importance of chemical factors, which can be further divided into two categories: A) essential nutrients and B) potentially toxic elements. We tested the following sub-hypotheses:

A. Low levels of important macronutrients or ratios $(\mathrm{N}, \mathrm{K}, \mathrm{Ca}, \mathrm{Ca}: \mathrm{Mg})$ limit plant growth on barren relative to vegetated soils. Support for this hypothesis would come from i) lower concentrations of these elements or ratios in soils and foliage collected from barren than from vegetated areas in the field, ii) experimental study plant biomass increases accompanying $\mathrm{N}, \mathrm{K}$, or $\mathrm{Ca}$ additions, and iii) significant positive correlations between foliar element or ratio concentrations and biomass across soil types and treatments in the experimental study

B. High levels of toxic elements ( $\mathrm{Mg}$, heavy metals such as $\mathrm{Ni}, \mathrm{Co}, \mathrm{Cr}$ ) limit plant growth on barren relative to vegetated soils. Support for this hypothesis would come from i) higher concentrations of $\mathrm{Mg}$ or heavy metals in soils and foliage collected from barren than from vegetated areas in the field, ii) higher concentrations of these elements in roots or shoots of plants grown in barren than vegetated soils in the experimental study, and iii) significant negative correlations between potentially toxic foliar elements and biomass across soil types and treatments in the experimental study
Understanding the barren-vegetated pattern is necessary for better understanding of the serpentine syndrome in general and for successful restoration of vegetation or shrub and tree islands on serpentine soil areas degraded by logging, mining, and off-highway vehicle use on the New Idria serpentine mass. Improved understanding is also important for activities that might facilitate conservation of endemic serpentine species. Understanding variation in species or functional group responses to different serpentine soils is of use to restoration practitioners, who need to amend degraded serpentine substrates to promote native plant growth without stimulating invasive species. Serpentine restoration and revegetation are of increasing importance because these soils, which support very high levels of biodiversity and endemic species relative to the extent of the area they occupy globally, are frequently heavily disturbed by recreational activities or by mercury, asbestos, nickel, and chromium mining (O’Dell and Claassen 2009).

\section{Methods}

Field soil and foliage collection and analyses

The New Idria serpentine mass is located at the southern end of the Diablo Range in the California Coast Ranges $\left(36.3^{\circ} \mathrm{N}, 120.6^{\circ} \mathrm{W}\right)$. The area experiences a Mediterranean-type climate (cool wet winters and hot dry summers) with mean annual precipitation of 40-60 cm (Alexander et al. 2007). Hydrothermal alteration has nearly completely transformed the original peridotite protolith to serpentinite which contains a high concentration of chrysotile asbestos (Coleman 1986). The serpentinite has been intensely sheared and crushed, resulting in a terrain of low, rounded hills with a strong tendency to slide when slopes become oversteepened. Barrens with shallow, soft, powdery soils are widely interspersed with densely vegetated areas of chaparral displaying more advanced soil development. Herbaceous cover is very sparse to non-existent in both barrens and chaparral.

We selected three pairs of barren and vegetated areas within the New Idria serpentine mass that met criteria of close physical proximity with similar slope, aspect, and elevation (Table 1, Online Resource Fig. 1). Within each barren area, we collected soils at 20-30 cm depth (rooting zone) on three randomly chosen mid-slope 
Table 1 Slope, elevation and aspect of three sites where soils and vegetation were sampled. Potential rooting depth was measured at four random locations within each of the three sites for each soil type (except off serpentine where only one site was sampled). Depth range is given because the soil depth probe could only measure to $1 \mathrm{~m}$, and soils were often deeper than that maximum. Cover was estimated for a $10 \mathrm{~m}$ radius around each site (mean $\pm \mathrm{SE}$ )

\begin{tabular}{|c|c|c|c|c|c|}
\hline Soil type & Slope $(\%)$ & Elevation (m) & Aspect $\left({ }^{\circ}\right)$ & Rooting depth range (m) & $\%$ Cover \\
\hline Barren & $25,25,24$ & $1070,1466,1341$ & $80,245,345$ & $0.15->1.00$ & $0 \pm 0$ \\
\hline Shrub Island & & & & $0.20->1.00$ & $33 \pm 5$ \\
\hline Vegetated & $13,22,22$ & $1067,1467,1292$ & $165,260,290$ & $0.15->1.00$ & $66 \pm 11$ \\
\hline Off serpentine & 35 & 810 & 260 & $0.12->1.00$ & 56 \\
\hline
\end{tabular}

barren locations and within three shrub/tree islands. On vegetated slopes, we collected soils at the same depth in three randomly-selected canopy gaps (though the steepness of the slopes and the high vegetative cover overall made canopy gaps similar in their surface properties to under-shrub areas). Coarse fragment volume was estimated in the field and added to the volume of any coarse fragments not passing the sieve during preparation of the soil for analyses.

Within each barren area, we collected mature evergreen foliage that grew the previous spring (collection was in early March 2008) from one Pinus sabiniana D. Don Pinaceae (foothill pine) and one Arctostaphylos glauca Lindl. Ericaceae (bigberry manzanita) in each of three shrub islands. Hereafter these species are referred to as Pinus and Arctostaphylos. Within each vegetated area, we located three Pinus individuals and collected foliage from these as well as from the nearest Arctostaphylos. For each individual, sampling occurred at random and included all sides of the canopy.

Soil was dried, sieved to $2 \mathrm{~mm}$, and submitted to A\&L Western Analytical Laboratories (Modesto, CA,

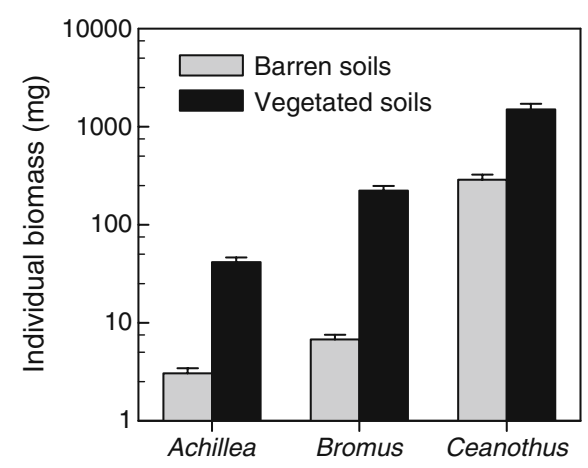

Fig. 1 Least squares means and SE $(n=16-24)$ for total plant biomass (root plus shoot) of the three study species grown in serpentine soils collected from barren and vegetated areas. Note $\log$ scale
USA) for analysis of organic matter (loss on ignition at $360^{\circ} \mathrm{C}$ ), $\mathrm{pH}$ (saturated paste), cation exchange capacity (CEC), extractable $\mathrm{Ca}, \mathrm{Mg}$, and $\mathrm{K}$ (ammonium acetate at $\mathrm{pH} 7$ ), bicarbonate extractable phosphorus $(\mathrm{P})$, nitrate $\mathrm{N}(2 \mathrm{M} \mathrm{KCl}$ extraction), and DTPA extractable iron (Fe), manganese $(\mathrm{Mn})$, zinc $(\mathrm{Zn})$, copper $(\mathrm{Cu})$, molybdenum (Mo), nickel $(\mathrm{Ni})$, cobalt (Co), and chromium (Cr). We measured total $\mathrm{N}$ by combustion on ball mill ground samples using a CHNSO analyzer (Costech Analytical Technologies, Valencia, CA, USA, Model ECS 4010). We also measured texture by fractionation and moisture release properties using weighing and a dewpoint water potential meter (Decagon Devices, Inc., Pullman, WA, USA; Model WP4).

We analyzed soil data by performing 18 univariate ANOVA's using a sequential Bonferroni correction (Rice 1990) to control family-wise type I error. Dependent variables were soil properties (e.g., pH, organic matter, Ni content) and independent variables were soil type, collection location (random), and their interaction. We performed Tukey-Kramer comparisons on soil type (barren, shrub island, vegetated) for soil properties with significant univariate models.

Foliage was washed with deionized water, dried for $48 \mathrm{~h}$ at $60^{\circ} \mathrm{C}$, and ground to 40 mesh in a Wiley mill. Samples were microwave digested with nitric acid and peroxide (Sah and Miller 1992) and analyzed for $\mathrm{Ca}, \mathrm{Mg}, \mathrm{K}, \mathrm{P}, \mathrm{Fe}, \mathrm{Mn}, \mathrm{Cu}, \mathrm{Mo}, \mathrm{Ni}, \mathrm{Co}$, and $\mathrm{Cr}$ concentrations on an ICP-MS (Agilent Technologies, Santa Clara, CA, USA, Model 7500a). Samples were further ground to a fine powder, packed in tin capsules, and analyzed for foliar $\mathrm{N}$ levels using the CHNSO analyzer.

We performed principal components analysis (PCA) of foliar elemental concentrations (Ca: $\mathrm{Mg}, \mathrm{K}$, $\mathrm{P}, \mathrm{N}, \mathrm{Fe}, \mathrm{Mn}, \mathrm{Cu}, \mathrm{Mo}, \mathrm{Ni}$, and $\mathrm{Cr}$; Co was excluded because it was below detection limit for all samples) 
for Pinus and Arctostaphylos. Data were log transformed prior to analysis. We performed ANOVA on the first three principal components (PC's), dependent variables, with soil type, collection location (random), species, and interactions as independent variables.

Plant growth on barren and vegetated soils

\section{Plant culture}

For the experimental study of plant growth on soils collected from barren and vegetated areas we chose plants of three functional groups commonly found at the field site and that could be effectively grown in pots. The field sampled Pinus and Arctostaphylos were not suitable for the pot study because of their large stature and slow growth. We grew three species - a native shrub (Ceanothus cuneatus (Hook.) Nutt.; Rhamnaceae; buckbrush), a native perennial forb (Achillea millefolium (L.); Asteraceae; common yarrow), and an invasive annual grass (Bromus madritensis ssp. rubens (L.) Husn.; Poaceae; red brome) in $650 \mathrm{~mL}$ pots using soils collected from the same paired barren and vegetated areas in which soil sampling occurred. Soils were from barren areas, not from shrub islands within barrens. Hereafter these three study species are referred to as Ceanothus, Achillea, and Bromus. Soil was sieved to $5 \mathrm{~mm}$ prior to planting. Ceanothus and Achillea seeds were collected from serpentine populations (at least 20 and 500 mothers, respectively) in the New Idria serpentine mass and pooled. Bromus seed was collected from at least 200 mothers in a single population growing on a serpentine outcrop near Colusa, California. Ceanothus seed was treated with hot water to break dormancy (Emery 1988), germinated in potting soil, and bare-rooted before planting into experimental pots. Seedlings were approximately $2 \mathrm{~cm}$ tall and had no branches at the time of repotting. Achillea and Bromus seeds were sown directly into experimental pots.

During the entire experiment plants grew outside on the University of California, Davis, CA, USA campus starting in April of 2008, and they were kept well-watered (twice daily with deionized water) to eliminate water deficit as a possible stressor and to remove potential soil type differences in physical properties. Excess water was not captured but allowed to drain away to prevent soil saturation effects. Pots were arranged in a completely randomized design, with two rows of empty edge pots ensuring that no experimental pot was heated by direct solar radiation from the side. Fertilization treatments applied weekly were doses of nutrient solution containing factorial combinations of dissolved $\mathrm{N}, \mathrm{K}$, and $\mathrm{Ca}$ (i.e., control, $+\mathrm{N},+\mathrm{K},+\mathrm{Ca},+\mathrm{NK},+\mathrm{NCa},+\mathrm{KCa},+\mathrm{NKCa})$ in the following amounts: $2.69 \mathrm{mMol} \mathrm{N}$ as $\mathrm{NH}_{4} \mathrm{NO}_{3}$, $0.93 \mathrm{mMol} \mathrm{K}$ as $\mathrm{KCl}$, and $9.42 \mathrm{mMol} \mathrm{Ca}$ as $\mathrm{CaCl}_{2}$. Ratios of $\mathrm{Ca}$ to other nutrients were based on literature (Chiarucci et al. 1999), and solution concentrations were adjusted to keep conductivities low enough for plants to tolerate. The choice of these elements $(\mathrm{N}, \mathrm{K}, \mathrm{Ca})$ for the factorial fertilization experiment was based on apparent deficiency revealed by soil analyses (see Results).

Above and belowground parts were harvested, washed, dried and weighed at 8, 9, and 16 weeks for Bromus, Achillea, and Ceanothus, respectively. A portion of the soil in each pot was washed to extract fine roots and another portion was dried for soil analyses. Roots were stored briefly in cold, deionized water and then scanned and root length measured with WinRHIZO (Regent Instruments Inc., Québec City, QC, Canada) prior to drying.

Biomass and root length density (km of root per cubic meter of soil) data were analyzed on a per individual basis and include only biomass produced during the course of the experiment for Ceanothus, which was transplanted as a seedling. We used a mixed model in JMP version 5.0.1 (SAS Institute, Cary, NC, USA) to perform ANOVA's with treatment, species (Achillea, Bromus, Ceanothus), soil type (barren/ vegetated), field soil collection location (random), and all possible 3-way interactions (the 4-way interaction was by definition the residual error). Data were $\log$ transformed prior to analysis to meet homogeneity of variance assumptions. Rather than including a general "treatment" factor in our models and then performing a large number of orthogonal contrasts after the fact, we included the factors $\mathrm{N}(+/-), \mathrm{K}(+/-)$, and $\mathrm{Ca}(+/-)$ and their interactions with each other and with species, soil type and collection location in the initial model (Online Resource Tables 1,2). Due to a logistical issue leading to the early demise of all Ceanothus in vegetated soil treated with both $\mathrm{Ca}$ and $\mathrm{K}$, it was not possible to analyze the experiment as an NKCa full factorial in a single ANOVA. Because preliminary analyses showed no significant effect of $\mathrm{K}$ addition on biomass or root length density, we removed the $\mathrm{K}$ factor from the 
Table 2 Mean \pm SE for chemical properties of field collected soils . Nonserpentine soil data are provided for comparison only and were not included in the statistical analyses. Soil types connected by the same letter did not differ significantly at the $5 \%$ level. Mo was below detection limit (BDL; $0.1 \mathrm{mg} \mathrm{kg}^{-1}$ ) in all soils

\begin{tabular}{|c|c|c|c|c|}
\hline & Barren & Shrub island within barren & Vegetated & Nonserpentine \\
\hline n locations & 3 & 3 & 3 & 1 \\
\hline n samples per location & 3 & 3 & 3 & 6 \\
\hline $\mathrm{pH}$ & $7.09 \pm 0.16$ & $7.39 \pm 0.05$ & $7.29 \pm 0.03$ & 7.48 \\
\hline Cation exhange capacity ( $\mathrm{cmol} / \mathrm{kg}$ ) & $2.94^{\mathrm{b}} \pm 0.44$ & $8.21^{\mathrm{a}} \pm 0.36$ & $10.84^{\mathrm{a}} \pm 0.42$ & 23.40 \\
\hline Organic matter $(\%)$ & $1.21^{\mathrm{b}} \pm 0.09$ & $3.39^{\mathrm{a}} \pm 0.51$ & $3.79^{\mathrm{a}} \pm 0.59$ & 2.58 \\
\hline Total N (\%) & $0.009^{c} \pm 0.003$ & $0.064^{\mathrm{b}} \pm 0.016$ & $0.104^{\mathrm{a}} \pm 0.030$ & 0.096 \\
\hline Nitrate $\mathrm{N}\left(\mathrm{mg} \mathrm{kg}^{-1}\right)$ & $5.90 \pm 0.99$ & $3.73 \pm 0.86$ & $5.38 \pm 1.15$ & 6.73 \\
\hline Bicarbonate extractable $\mathrm{P}\left(\mathrm{mg} \mathrm{kg}^{-1}\right)$ & $5.28 \pm 0.93$ & $6.06 \pm 0.51$ & $9.38 \pm 0.93$ & 4.10 \\
\hline $\mathrm{K}\left(\mathrm{mg} \mathrm{kg}^{-1}\right)^{*}$ & $9.3^{\mathrm{b}} \pm 5.9$ & $25.4^{\mathrm{a}} \pm 0.6$ & $39.5^{\mathrm{a}} \pm 3.3$ & 294.7 \\
\hline $\mathrm{Ca}\left(\mathrm{mg} \mathrm{kg}^{-1}\right)^{*}$ & $68.7^{\mathrm{c}} \pm 11.6$ & $233.9^{\mathrm{b}} \pm 34.2$ & $514.6^{\mathrm{a}} \pm 8.4$ & 3924.2 \\
\hline $\operatorname{Mg}\left(\mathrm{mg} \mathrm{kg}^{-1}\right)^{*}$ & $303.4^{\mathrm{b}} \pm 49.1$ & $842.5^{\mathrm{a}} \pm 25.6$ & $988.1^{\mathrm{a}} \pm 49.2$ & 363.0 \\
\hline Ca:Mg (molar ratio) & $0.16^{\mathrm{b}} \pm 0.03$ & $0.16^{\mathrm{b}} \pm 0.02$ & $0.32^{\mathrm{a}} \pm 0.01$ & 9.2 \\
\hline $\mathrm{Fe}\left(\mathrm{mg} \mathrm{kg}^{-1}\right)^{* *}$ & $2.28^{\mathrm{b}} \pm 1.19$ & $6.42^{\mathrm{a}} \pm 2.96$ & $8.30^{\mathrm{a}} \pm 3.37$ & 5.25 \\
\hline $\operatorname{Mn}\left(\mathrm{mg} \mathrm{kg}^{-1}\right)^{* *}$ & $0.86^{\mathrm{c}} \pm 0.06$ & $3.89^{\mathrm{b}} \pm 1.08$ & $5.80^{\mathrm{a}} \pm 0.45$ & 3.33 \\
\hline $\mathrm{Zn}\left(\mathrm{mg} \mathrm{kg}^{-1}\right)^{* *}$ & $0.11 \pm 0.01$ & $0.10 \pm 0.00$ & $0.16 \pm 0.01$ & 0.37 \\
\hline $\mathrm{Cu}\left(\mathrm{mg} \mathrm{kg}^{-1}\right)^{* *}$ & $0.16 \pm 0.04$ & $0.14 \pm 0.03$ & $0.19 \pm 0.03$ & 0.90 \\
\hline $\mathrm{B}\left(\mathrm{mg} \mathrm{kg}^{-1}\right)$ & $0.21 \pm 0.03$ & $0.41 \pm 0.07$ & $0.39 \pm 0.05$ & 0.83 \\
\hline Mo $\left(\mathrm{mg} \mathrm{kg}^{-1}\right)^{* *}$ & BDL & BDL & BDL & $\mathrm{BDL}$ \\
\hline $\mathrm{Ni}\left(\mathrm{mg} \mathrm{kg}^{-1}\right)^{* *}$ & $1.77^{\mathrm{b}} \pm 0.50$ & $13.70^{\mathrm{a}} \pm 1.06$ & $21.29^{\mathrm{a}} \pm 2.28$ & 0.27 \\
\hline $\mathrm{Co}\left(\mathrm{mg} \mathrm{kg}^{-1}\right)^{* *}$ & $0.10 \pm 0.00$ & $0.24 \pm 0.06$ & $0.32 \pm 0.02$ & 0.10 \\
\hline $\mathrm{Cr}\left(\mathrm{mg} \mathrm{kg}^{-1}\right)^{* *}$ & $1.51^{\mathrm{a}} \pm 0.14$ & $0.21^{\mathrm{b}} \pm 0.08$ & $0.24^{\mathrm{b}} \pm 0.13$ & 0.22 \\
\hline
\end{tabular}

*Exchangeable

**DTPA extractable

model and present an $\mathrm{NCa}$ full factorial. We performed orthogonal linear contrasts on least squares means to better understand soil type differences within species or treatment differences within soil type and species.

\section{Tissue analyses}

Leaf tissues from all plants and root tissues from a subset of plants (control and $+\mathrm{Ca}$ treatments) were rinsed well in distilled deionized water, dry ashed for $6 \mathrm{~h}$ at $450^{\circ} \mathrm{C}$ and re-suspended in $3 \%$ nitric acid. Solution $\mathrm{Ca}, \mathrm{Mg}, \mathrm{K}, \mathrm{Fe}, \mathrm{Mn}, \mathrm{Zn}, \mathrm{Cu}, \mathrm{Mo} \mathrm{Ni}, \mathrm{Co}$, and $\mathrm{Cr}$ concentrations were measured on the ICP-MS. Leaf tissue from a subset of plants (control and $+\mathrm{N}$ treatments) was ground, packed in tin capsules, and analyzed for foliar N levels using the CHNSO analyzer.

Foliar elemental data (other than N) were analyzed using the same mixed model ANOVA described for biomass for each of the foliar elemental concentrations with a sequential Bonferroni correction on each whole model fit to control for experiment-wide type I error (note - $P$-values all $<0.0001$ or $>0.05$ ). Data were $\log$ transformed prior to analysis for homogeneity of variance. Because treatments had no impact on foliar elements other than the ones we added (i.e., N, K, and $\mathrm{Ca}$ ), we report least squares means of the $\mathrm{N} \times \mathrm{Ca}$ full factorial analyses for all elements except $\mathrm{K}$ (for which we report the results of an $\mathrm{N} x \mathrm{~K}$ full factorial). Foliar $\mathrm{N}$ concentrations were analyzed separately, as this variable was measured only for control and $+\mathrm{N}$ treatments. This ANOVA included species, treatment (control or $+\mathrm{N}$ ), soil type, collection location, and all possible 3-way interactions that did not include collection location.

For roots, where elemental concentration measurements were made only on control and $+\mathrm{Ca}$ treatments, we analyzed $\mathrm{Mg}$ and heavy metal (Fe, $\mathrm{Mn}, \mathrm{Zn}, \mathrm{Cu}, \mathrm{Ni}$, $\mathrm{Co}, \mathrm{Cr}$ ) concentrations using individual univariate mixed model ANOVA's with a sequential Bonferroni 
correction to control for experiment-wide type I error. Data were $\log$ transformed prior to analysis for homogeneity of variance. Because preliminary results showed that $\mathrm{Ca}$ addition did not significantly affect the concentrations of these elements, we removed the treatment factor from the model for these analyses, which had dependent variable concentration and independent variables soil type, species, collection location (random), and their interactions. We compared least squares means for the species $\mathrm{x}$ soil type interaction using Tukey-Kramer comparisons. We also calculated foliage:root concentration ratios to represent patterns of translocation from roots to aboveground parts and performed the same set of analyses. Foliage:root values $>1$ suggest preferential net translocation to leaves, whereas values $<1$ suggest root sequestration or poor translocation to leaves. Data were log transformed prior to analysis for homogeneity of variance. We analyzed root $\mathrm{Ca}, \mathrm{Ca}: \mathrm{Mg}$, and foliage:root $\mathrm{Ca}$ with an ANOVA that included species, soil type (barren/ vegetated), treatment $(-/+\mathrm{Ca})$, and their interactions (collection location was treated as a replicate). Log transformations were not needed for these data.

We calculated $r^{2}$ values and growth response coefficients (GRC's) for the logarithmic relationships between foliar elemental concentrations and biomass for each species. GRC's (slopes of log-log plots of a variable vs. growth, Poorter and van der Werf 1998) measure the proportional change in a variable that accompanies a proportional change in growth rate. Poorter and van der Werf, who developed this concept, used it to distinguish between competing hypotheses with respect to the most important explanatory variables for growth rate (i.e., Net Assimilation Rate and Leaf Area Ratio), interpreting the variable with the largest GRC as the one of greatest importance. They favored GRC's over correlation coefficients for this purpose because correlation coefficients measure relative variation around the mean but do not take the absolute size of that variation into account. We follow their interpretation here.

\section{Results}

Rooting depth and soil physical properties

Across the New Idria serpentine mass, barrens occurred on all aspects and on slopes that were flat enough for vegetation establishment, based on comparison to adjacent vegetated slopes (Table 1; Online Resource Fig. 1). Soil pits show that true soils on the New Idria barrens are quite shallow $(18-30 \mathrm{~cm})$ but overlie $30-50 \mathrm{~cm}$ of highly weathered and fractured bedrock (Soil Survey Staff 2010). This agrees well with our soil probe measurements, showing potential rooting depths for all three soil types were quite deep $(>1 \mathrm{~m})$ and did not differ among the three types (Table 1). Barren soil (bare area) textures were sands $(\%$ sand $/$ silt/clay $=87 / 8 / 5)$, shrub-island soils within barrens were loamy sands (79/13/8), and vegetated soils were sandy loams $(69 / 5 / 26)$. Vegetated soils had more clay $(P=0.039)$ and less sand $(P=0.011)$ than soils collected on barrens (both shrub islands and bare areas - orthogonal contrasts). Within barrens, the trends for more clay and less sand in shrub islands than bare areas were not statistically significant $(P=$ 0.78 and $P=0.12$, respectively).

Mean $( \pm \mathrm{SE} ; n=3)$ available soil water of the $<2 \mathrm{~mm}$ fraction of these sandy soils between -0.01 and $-1.5 \mathrm{MPa}$, calculated from moisture release curves, was not significantly different (paired $t$-test, $P=0.87)$ between barren $\left(0.140 \pm 0.021 \mathrm{~m}^{3} \mathrm{~m}^{-3}\right)$ and vegetated $\left(0.153 \pm 0.067 \mathrm{~m}^{3} \mathrm{~m}^{-3}\right)$ soils (Online Resource Table 3). Extending the low water potential cutoff to $-5.0 \mathrm{MPa}$, because of drought tolerant native species, did not result in any significant difference (Online Resource Table 3). Including the coarse fraction ( $>2 \mathrm{~mm}$ diameter) also showed no significant difference (paired $t$-test, $P=0.77$ ) in available water between -0.01 and $-1.5 \mathrm{MPa}$ between barren $\left(0.096 \pm 0.015 \mathrm{~m}^{3} \mathrm{~m}^{-3}\right)$ and vegetated $\left(0.114 \pm 0.049 \mathrm{~m}^{3} \mathrm{~m}^{-3}\right)$ soils.

\section{Soil chemistry}

Vegetated and shrub-island soils had greater CEC, organic matter, $\mathrm{K}, \mathrm{Mg}, \mathrm{Fe}$, and $\mathrm{Ni}$ and less $\mathrm{Cr}$ than barren soils (Table 2). Barren and shrub-island soils had lower $\mathrm{Ca}: \mathrm{Mg}$ than vegetated soils. $\mathrm{Mn}$ and $\mathrm{Ca}$ were greatest on vegetated soils, least on barren soils, and intermediate on shrub-island soils. Many soil properties and elements showed strong correlations (Online Resource Table 4). The highest concentrations of $\mathrm{Ca}, \mathrm{Mg}, \mathrm{K}, \mathrm{Ni}$, and $\mathrm{Mn}$ were measured on soils with the greatest CEC, organic matter, and total carbon, all of which were closely related. 
Table 3 Mean \pm SE elemental concentrations in field-collected foliage of Arctostaphylos glauca and Pinus sabiniana on serpentine soils $(n=3$ locations with 3 samples per location)

\begin{tabular}{|c|c|c|c|c|}
\hline & \multicolumn{2}{|c|}{ Arctostaphylos glauca } & \multicolumn{2}{|l|}{ Pinus sabiniana } \\
\hline & Shrub island & Vegetated & Shrub island & Vegetated \\
\hline N (\%) & $0.724 \pm 0.098$ & $0.829 \pm 0.015$ & $1.058 \pm 0.064$ & $1.106 \pm 0.016$ \\
\hline $\mathrm{P}\left(\mathrm{g} \mathrm{kg}^{-1}\right)$ & $0.551 \pm 0.082$ & $0.674 \pm 0.165$ & $0.923 \pm 0.076$ & $0.969 \pm 0.070$ \\
\hline $\mathrm{K}\left(\mathrm{g} \mathrm{kg}^{-1}\right)$ & $3.54 \pm 0.25$ & $4.45 \pm 1.59$ & $3.74 \pm 0.37$ & $4.71 \pm 1.01$ \\
\hline $\mathrm{Ca}\left(\mathrm{g} \mathrm{kg}^{-1}\right)$ & $5.88 \pm 0.75$ & $9.40 \pm 2.31$ & $1.99 \pm 0.41$ & $1.98 \pm 0.69$ \\
\hline $\operatorname{Mg}\left(\mathrm{g} \mathrm{kg}^{-1}\right)$ & $3.92 \pm 0.23$ & $3.75 \pm 0.62$ & $2.61 \pm 0.18$ & $2.01 \pm 0.32$ \\
\hline $\mathrm{Ca}: \mathrm{Mg}$ & $0.90 \pm 0.03$ & $1.42 \pm 0.29$ & $0.46 \pm 0.10$ & $0.60 \pm 0.14$ \\
\hline $\mathrm{Fe}\left(\mathrm{mg} \mathrm{kg}^{-1}\right)$ & $51.07 \pm 8.42$ & $29.85 \pm 3.06$ & $93.63 \pm 16.58$ & $56.06 \pm 6.57$ \\
\hline $\operatorname{Mn}\left(\mathrm{mg} \mathrm{kg}^{-1}\right)$ & $15.16 \pm 0.60$ & $22.22 \pm 3.70$ & $64.24 \pm 7.75$ & $56.60 \pm 15.19$ \\
\hline $\mathrm{Cu}\left(\mathrm{mg} \mathrm{kg}^{-1}\right)$ & $0.88 \pm 0.10$ & $1.37 \pm 0.50$ & $1.32 \pm 0.19$ & $1.24 \pm 0.34$ \\
\hline Mo $\left(\mu \mathrm{g} \mathrm{kg}^{-1}\right)$ & $24.67 \pm 1.79$ & $15.09 \pm 6.80$ & $43.51 \pm 10.3$ & $34.98 \pm 7.46$ \\
\hline $\mathrm{Ni}\left(\mathrm{mg} \mathrm{kg}^{-1}\right)$ & $3.03 \pm 0.75$ & $4.35 \pm 1.00$ & $2.15 \pm 0.14$ & $2.56 \pm 0.37$ \\
\hline Co $\left(\mathrm{mg} \mathrm{kg}^{-1}\right)$ & BDL & $\mathrm{BDL}$ & BDL & BDL \\
\hline $\mathrm{Cr}\left(\mathrm{mg} \mathrm{kg}^{-1}\right)$ & $3.95 \pm 0.75$ & $6.10 \pm 2.17$ & $2.53 \pm 0.53$ & $2.75 \pm 0.88$ \\
\hline
\end{tabular}

Field-collected foliage

Measured foliar concentrations of Arctostaphylos and Pinus are presented in Table 3. Overall $67.1 \%$ of the variation in elemental composition between these two species on the two soil types was captured with the PCA (Table 4). PC1 explained $37.5 \%$ of the variation and was related most strongly to species differences Positive loadings were elements for which Pinus concentrations were greater than Arctostaphylos concentrations (N, P, K, Fe, Mn, Mo), and negative loadings were elements for which the reverse was true (Ca:Mg, Ni, Cr).

PC2 explained $16.3 \%$ of the total variation. ANOVA with PC2 as the dependent variable was not quite significant $(P=0.095)$, and soil type $\mathrm{x}$ genus $(P=0.131)$, was the most nearly significant effect. PC2 and the elements with positive loadings $(\mathrm{N}, \mathrm{Ca}$ : $\mathrm{Mg}, \mathrm{Cu}, \mathrm{Ni}, \mathrm{Cr}$ ) all showed a soil type difference (vegetated > barren) for Arctostaphylos, and no difference or a smaller difference for Pinus.

PC3 explained $13.3 \%$ of the total variation. ANOVA with PC3 as the dependent variable showed a nearly significant $(P=0.073)$ effect of soil type. Elements with strong positive loadings (Fe, Mo) had higher concentrations in foliage of both species collected on barrens. K, and P, with weaker negative loadings showed slightly higher concentrations in foliage collected on vegetated soils for both species.
Plant growth on barren and vegetated soils

Biomass was substantially greater, by 5-, 14-, and 33fold for Ceanothus, Achillea, and Bromus, respectively, when grown on soil collected from vegetated areas than on soil collected from adjacent barren areas (significant soil type $\mathrm{x}$ species interaction, Fig. 1, Online Resource Table 1). Biomass differences due to fertilizer treatments were small compared to the large species and soil type differences (Fig. 2). In single or factorial nutrient addition studies, increases in biomass that accompany increases in foliar concentration of a particular element with fertilization are interpreted as evidence of limitation by that element for that species in the unfertilized soil (James et al. 2005; model in Fig. 2). Ceanothus grown on barren soils responded positively to $\mathrm{N}$ and $\mathrm{Ca}$ addition, and Bromus grown on barren soils responded negatively to $\mathrm{N}$ addition (Fig. 2, orthogonal linear contrasts on significant soil type $\times$ species $\times \mathrm{N} \times \mathrm{Ca}$ interaction LS means for NCa model, Online Resource Table 1). No other significant fertilizer treatment effects on biomass were detected. Lack of growth response to treatments, at least on barren soils, was not due to lack of treatment element availability, particularly in the case of $\mathrm{Ca}$. In general, foliar concentrations increased with treatments, though sometimes more on barren than vegetated soils (Fig. 2, orthogonal linear contrasts for species $\times$ soil type $\times \mathrm{N}$ for $\mathrm{N}$ concentration, species $\times$ soil type $\times \mathrm{Ca}$ with $\mathrm{NCa}$ 
Table 4 Principal components analysis (PCA) and probability values for ANOVA on PCA scores for field-collected foliar elemental concentrations. These data are for Arctostaphylos and Pinus collected at three locations on two serpentine soil types (vegetated and shrub island within barren). Strongest loadings for eigenvectors and lowest probabilities for ANOVA's are indicated in bold text. $\mathrm{CL}=$ collection location

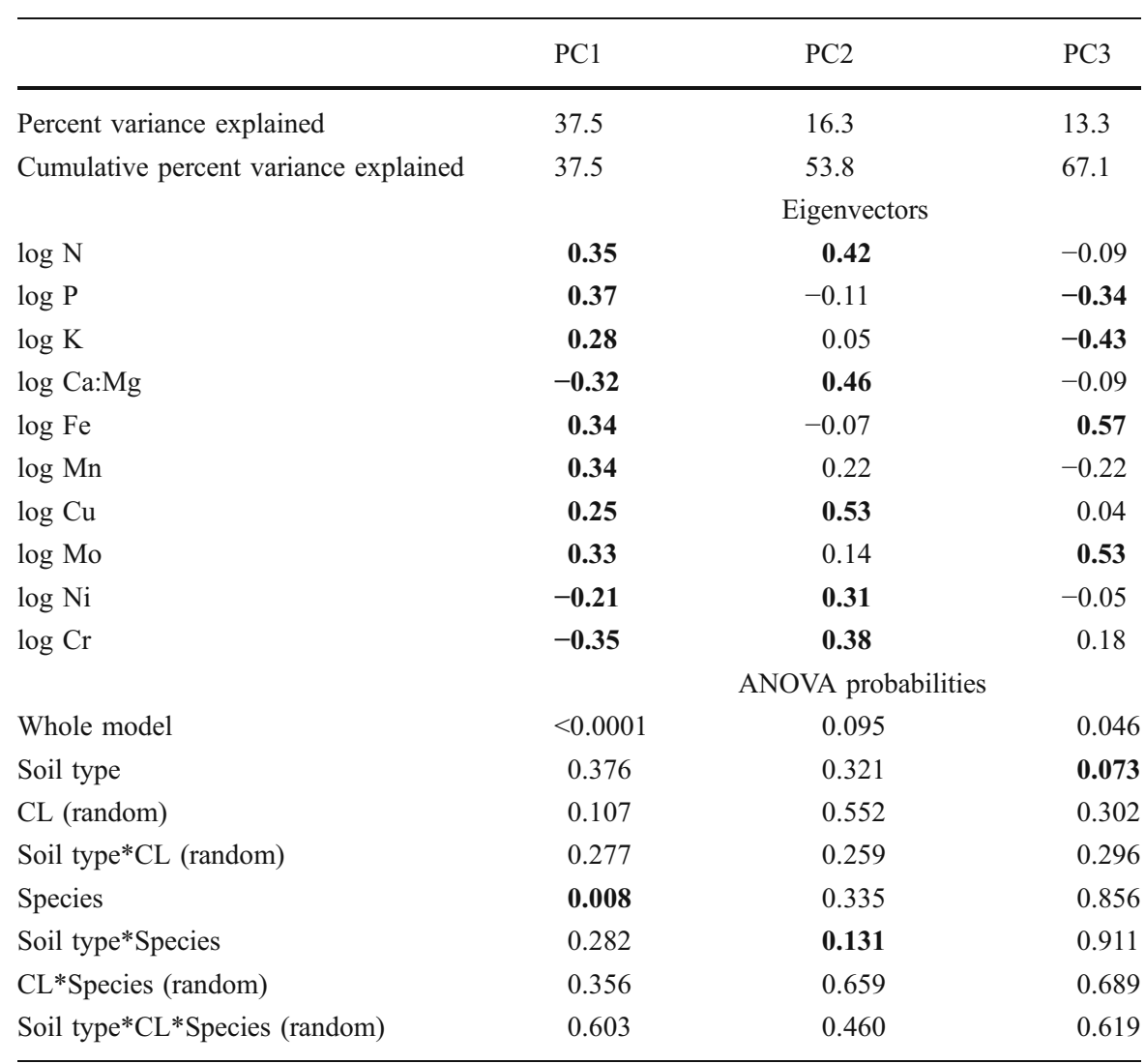

model for $\mathrm{Ca}$ concentration, species $\times$ soil type $\times \mathrm{K}$ with NK model for $\mathrm{K}$ concentration). Root length density was greater on vegetated than barren soils and increased slightly but significantly with added $\mathrm{Ca}$ on barren soils only (Fig. 3, Online Resource Table 2).

Foliar $\mathrm{Mg}$ and heavy metal (Fe, $\mathrm{Mn}, \mathrm{Zn}, \mathrm{Cu}$, $\mathrm{Mo}, \mathrm{Ni}, \mathrm{Co}$, and $\mathrm{Cr}$ ) concentrations were significantly higher on barren than vegetated soils for Achillea and Bromus (except $\mathrm{Mn}$ and $\mathrm{Mo}$ for Achillea). Ceanothus differences were nonsignificant, except in the case of $\mathrm{Cu}$, where vegetated was greater than barren (Fig. 4, orthogonal contrasts for species $\mathrm{x}$ soil type interactions, least squares means obtained from $\mathrm{NCa}$ models). Without added $\mathrm{Ca}$, all species showed significantly higher foliar $\mathrm{Ca}$ and $\mathrm{Ca}: \mathrm{Mg}$ ratios for vegetated than barren soils (Fig. 2, linear contrasts for species $\times$ soil type $\times \mathrm{Ca}$ least squares means for $\mathrm{NCa}$ model). With added $\mathrm{Ca}$, foliar $\mathrm{Ca}$ concentrations on barren soils surpassed those on vegetated soils for Achillea and Bromus. Foliar Ca:Mg showed a greater proportional increase on barren than vegetated soils with added $\mathrm{Ca}$, but absolute levels did not surpass those of vegetated soils with added $\mathrm{Ca}$ (Fig. 2).

On barren soils Achillea and Bromus roots had significantly higher concentrations of potentially toxic elements ( $\mathrm{Mg}, \mathrm{Fe}, \mathrm{Ni}, \mathrm{Co}, \mathrm{Cr}$ ) than Ceanothus, suggesting better avoidance of toxicity in the shrub. On vegetated soils where metal toxicity was less apparent, the difference between the species was not present (Fig. 5). For Achillea and Bromus but not for Ceanothus, root concentrations of potentially toxic elements ( $\mathrm{Mg}, \mathrm{Fe}, \mathrm{Mn}, \mathrm{Ni}, \mathrm{Co}, \mathrm{Cr}$ ) were higher for plants grown on barren versus vegetated soil, although these differences were not always significant (Fig. 5). This again is consistent with Ceanothus avoiding metal toxicity on barren soils better than Achillea and Bromus. In all but one case, shoot concentrations of $\mathrm{Mg}$ and heavy metals increased more than root concentrations on barren relative to vegetated soils, suggesting limited capacity to sequester potentially toxic elements in roots on these soils for all three species. Nevertheless, on both soils Ceanothus protected shoots from high concentrations 
Fig. 2 Least squares means for biomass plotted against foliar elemental concentrations for the three study species grown on two types of serpentine soils (barren $=$ $\mathrm{b}$, vegetated $=\mathrm{v}$ ). Uppercase letters represent all treatments for which the element on the $\mathrm{x}$-axis was added, while lowercase letters represent all treatments for which it was not added. Arrows denote significant concentration increases $(P<$ 0.05 , based on orthogonal linear contrasts for species $\times$ soil type $\times$ element). Asterisks denote significant biomass increases or decreases. The plotted locations of the upper or lower-case letters are the locations of the data values (arrows were drawn in manually). Model in upper right after James et al. (2005). Note log scales
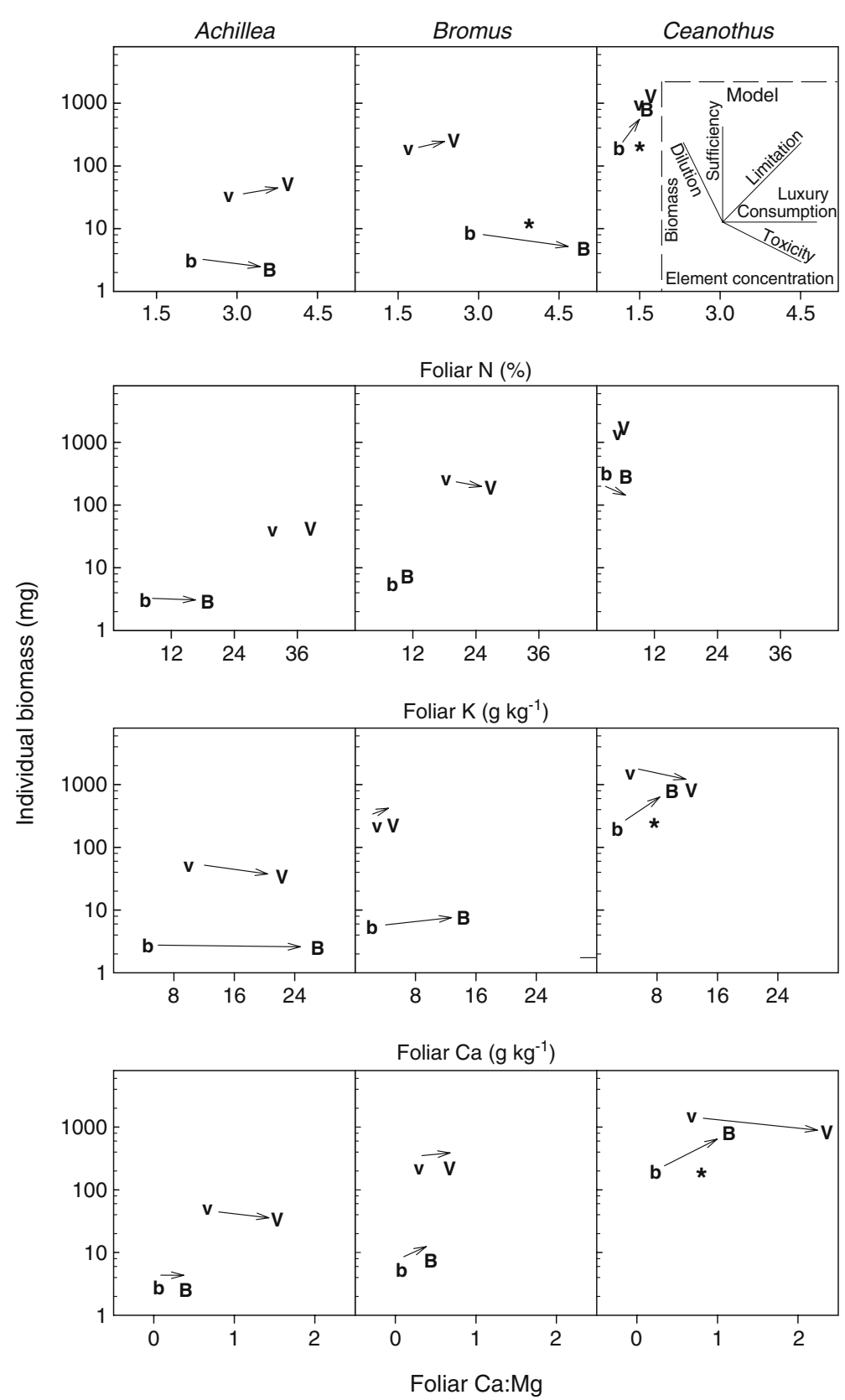

of these potentially toxic elements better than the other two species (especially $\mathrm{Fe}, \mathrm{Mn}, \mathrm{Cu}, \mathrm{Ni}, \mathrm{Co}, \mathrm{Cr}$, Fig. 6). Although we measured heavy metal concentrations in Ceanothus foliage only and not in stems, O'Dell et al. (2006) found low Ni and Mn concentrations in Ceanothus stems relative to foliage. Thus, we are confident that Ceanothus does not sequester heavy metals in stem tissue. Ceanothus maintained the highest root $\mathrm{Ca}: \mathrm{Mg}$ ratio of the three species on barren soil (Online Resource Fig. 2), which it achieved not by taking up more $\mathrm{Ca}$, but by maintaining lower Mg levels (Fig. 5). It also showed the most homeostatic translocation of $\mathrm{Ca}$ from roots to foliage between the two soils types (Online Resource Fig. 2).

For Achillea and Bromus, log biomass was strongly negatively correlated with $\log$ of foliar $\mathrm{Mg}$ and heavy metal concentrations (particularly $\mathrm{Fe}, \mathrm{Co}, \mathrm{Ni}$, and $\mathrm{Cr}$ ), though the relative strengths of the correlations varied 


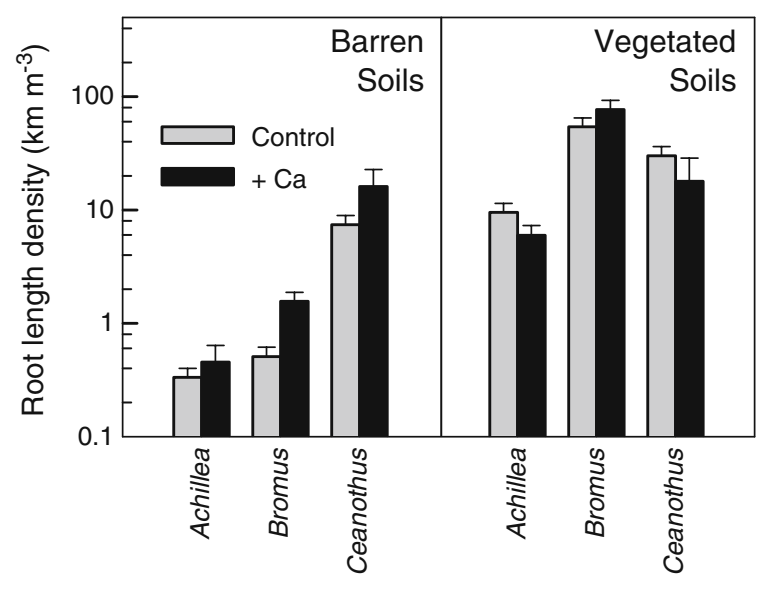

Fig. 3 Least squares means and SE $(n=5-12)$ for root length density of the three study species grown in serpentine soils collected from barren and vegetated areas. Note log scales

with species (Fig. 7). Log biomass for Ceanothus was correlated only with $\mathrm{Mg}$ (negatively) and $\mathrm{Ca}: \mathrm{Mg}$ (positively). This suggests that heavy metals may play an important role in limiting growth on these soils for Achillea and Bromus but not for Ceanothus, while $\mathrm{Ca}$ and/or $\mathrm{Mg}$ (or $\mathrm{Ca}: \mathrm{Mg}$ ) limit growth for all three species.

\section{Discussion}

Large differences observed in plant growth under well-watered conditions indicate that soil chemistry is an important factor maintaining the barren-vegetated pattern. While the fine-scale physical differences we measured may also play a role, they were relatively small, leading us to focus on the larger differences we observed in soil chemistry. More work could be done in the laboratory or the field to better ascertain the relative importance of the small but significant soil texture differences we measured.

While soil chemistry is of clear importance in maintaining the barren-vegetated pattern at New Idria, the relative importance of the various soil chemical properties varied from one species or functional group to another. In particular, Achillea and Bromus were strongly affected by heavy metal availability on barren soils, while Ceanothus was able to protect its shoots from high metal concentrations by exclusion and limited root-to-shoot translocation. Supporting evidence for this includes 1) the lesser degree of growth reduction for Ceanothus than for the other two

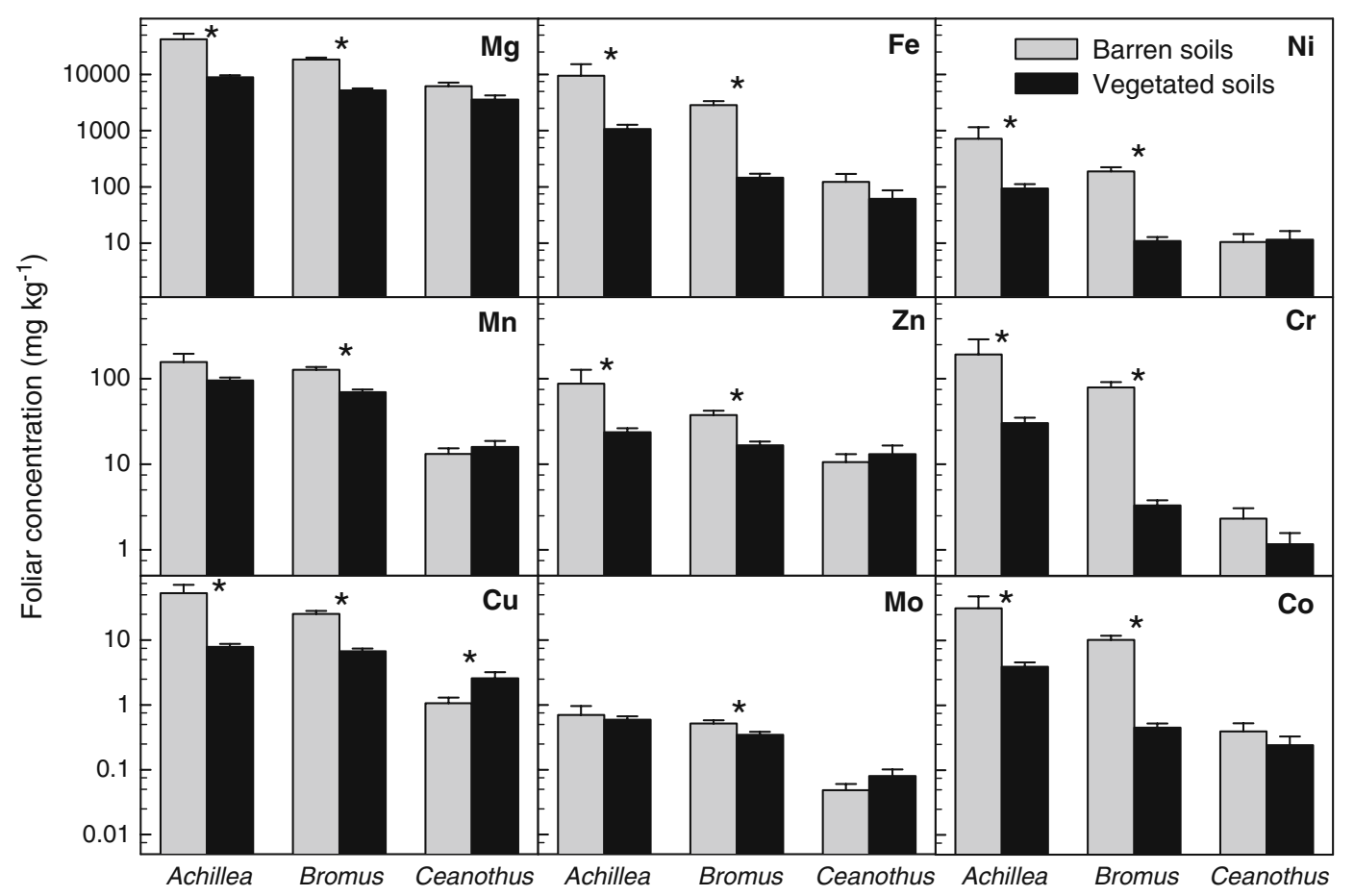

Fig. 4 Least squares means and SE $(n=14-24)$ for foliar elemental concentrations of the three study species grown in serpentine soils collected from barren and vegetated areas.
Asterisks denote significant soil type difference within species $(P<0.05$ in orthogonal linear contrasts $)$. Note log scales 


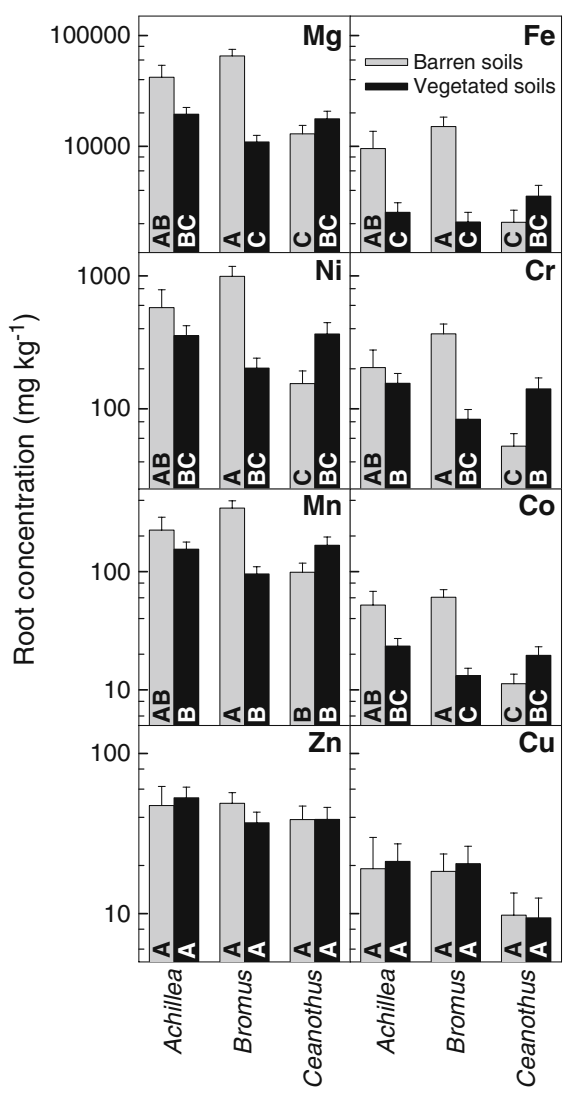

Fig. 5 Least squares means and SE $(n=4-6)$ for root $\mathrm{Mg}$ and heavy metal concentrations for the three study species grown in serpentine soils collected from barren and vegetated areas. Letters denote results of Tukey-Kramer comparisons for species $\times$ soil type LS means - values not connected by the same letter were significantly different $(P<0.05)$. Note log scales

species on barren relative to vegetated soils; 2) the positive response of Ceanothus to $\mathrm{N}$ and $\mathrm{Ca}$ on barren soils, which was lacking for the other two species; and 3 ) the highly significant log-log relationships between biomass and foliar heavy metal concentrations for Achillea and Bromus combined with the lack of this relationship in Ceanothus. The fact that these relationships extended to vegetated serpentine soils indicates that heavy metals limited the growth of these species, albeit to a lesser degree, on these soils as well. The root metal concentration pattern suggests a mechanism for this difference in metal tolerance, indicating that Ceanothus may both take up and translocate lesser quantities of these metals from roots to shoots.

While it is clear that $\mathrm{Mg}$ and heavy metals limited growth of Achillea and Bromus, particularly on barren soils, neither $\mathrm{Mg}$ nor any one heavy metal distin-

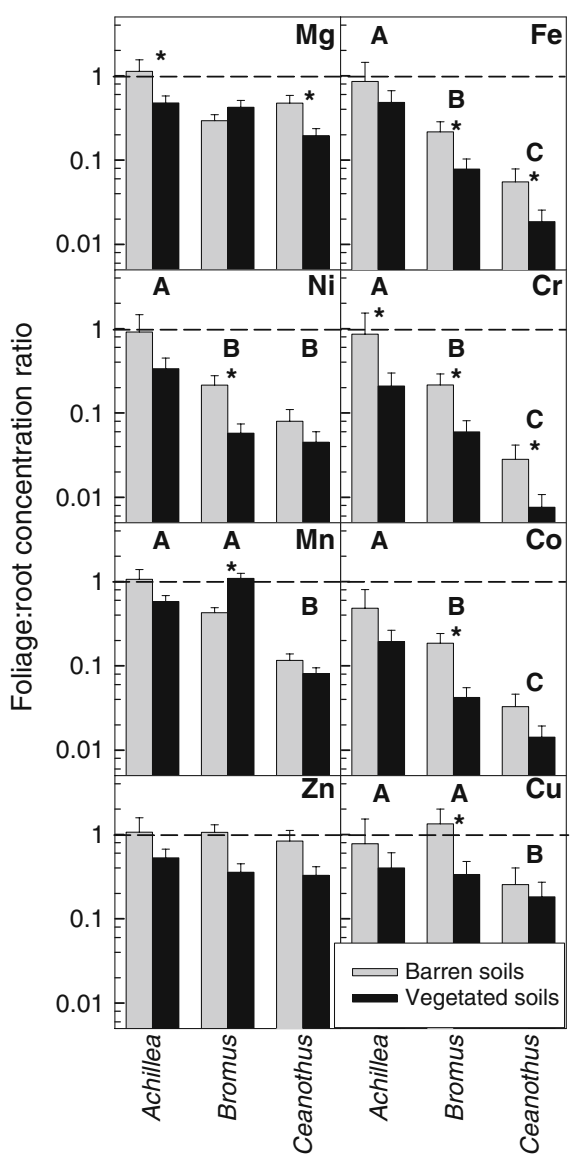

Fig. 6 Least squares means and SE $(n=4-6)$ for foliage:root concentration ratios for $\mathrm{Mg}$ and heavy metals for the three study species grown in serpentine soils collected from barren and vegetated areas. Reference line at 1 represents equal root and shoot concentrations. Asterisks indicate significant soil type differences within a species $(P<0.05$, orthogonal linear contrasts within species $\times$ soil type interaction), and letters show overall species differences (Tukey-Kramer- species not connected by the same letter were significantly different). Note log scale

guished itself from the others as the strongest cause of growth limitation. A principal components analysis on pot study foliar data yielded a first principal component that explained $68 \%$ of the total variation and had relatively even loadings for $\mathrm{Mg}, \mathrm{Fe}, \mathrm{Mn}, \mathrm{Cu}$, $\mathrm{Ni}, \mathrm{Co}$, and $\mathrm{Cr}(0.32-0.35)$. Absolute values of growth response coefficients (slopes of log-log plots between foliar elements and biomass) were greatest for $\mathrm{Cr}, \mathrm{Co}, \mathrm{Ni}$, and $\mathrm{Fe}$ for Bromus and $\mathrm{Ca}: \mathrm{Mg}, \mathrm{Fe}, \mathrm{Co}$, and $\mathrm{Cr}$ for Achillea (coefficients listed in order of magnitude, all coefficients were negative except $\mathrm{Ca}$ : $\mathrm{Mg}$, Fig. 7). In addition, foliar concentrations of $\mathrm{Mg}$ and many heavy metals were highly positively correlated in Achillea and Bromus foliage, but only 
moderately correlated in Ceanothus foliage (Online Resource Table 5). Lyon et al. (1971) also reported significant positive correlations between $\mathrm{Mg}$ and some heavy metals in New Zealand serpentine species, and Shewry and Peterson (1976) observed positive correlations between shoot $\mathrm{Cr}$ and $\mathrm{Ni}$ for 5 of 8 species growing in UK serpentine soils. Yang et al. (1985) found positive correlations among $\mathrm{Fe}, \mathrm{Mn}, \mathrm{Ni}$, $\mathrm{Co}$, and $\mathrm{Cr}$ concentrations in foliage of woody species growing on New Caledonia serpentine soils. We hypothesize that uptake of $\mathrm{Mg}$ and heavy metals may be correlated. While some transporters are specific to a particular metal, others have been shown to transport multiple metals (Hall and Williams 2003). In addition, plant-released reducing or chelating agents needed for Fe uptake may also reduce $\mathrm{Cu}$ or mobilize Zn (Palmer and Guerinot 2009).

Interestingly, we measured higher $\mathrm{Fe}, \mathrm{Mn}$, and $\mathrm{Ni}$ concentrations on vegetated than barren soils, but found the opposite pattern in foliage and roots of Achillea and Bromus grown on these soils. Vegetated soils were also significantly higher in organic matter, which has been shown to chelate heavy metals, reducing their uptake by plants (Halstead 1968; O’Dell and Claassen 2006). Fernandez et al. (1999) measured increased available $\mathrm{Mn}$ and $\mathrm{Ni}$ with organic matter (peat moss) addition to a serpentine soil (perhaps because of a reduction in $\mathrm{pH}$ that made these metals more soluble) but decreased concentrations in plant tissue and increased biomass relative to plants on untreated serpentine soil. They also measured relatively high $\mathrm{Cr}$ in plants growing on these soils despite low levels of available soil Cr. Robinson et al. (1999) found that adding chelators (NTA, DTPA, EDTA) to a serpentine soil decreased plant Ni uptake but increased (ammonium acetate) extractable Ni and Co. Together these studies suggest that chelated heavy metals (whether chelated by organic matter or some other means) may be relatively unavailable for plant uptake but still detectable by soil extraction methods, and this provides a possible explanation for our seemingly opposite soil and foliar heavy metal patterns (i.e., the higher concentrations of heavy metals we measured on vegetated soils may have been chelated by the greater organic matter present in these soils and unavailable for uptake). These results and ours highlight the difficulty of measuring truly plant-available heavy metals on serpentine soils and emphasize the importance of measuring plants grown on these soils as well. Our results also point out the need to base conclusions on multiple species if possible, as species clearly deal differently with metals.

Despite careful washing of foliage and roots, we considered the possible effects of soil contamination, particularly on 1) small herbaceous plants growing close to the surface on barren soils and 2) roots in general. While some contamination of roots with soil particles is likely in any study of this kind, we rejected the hypothesis that contamination drove the foliar or root element concentration patterns we observed. For foliage, strong relationships between biomass and foliar elemental concentrations (including heavy metals) existed for the herbaceous species, and these relationships extended into the vegetated soils, where the herbaceous species were not small in stature and hence were very unlikely to have been contaminated. For roots, if Ceanothus roots had lower metal concentrations on barren soils than the other species due only to less contamination conferred by their woodier character (smaller surface area relative to total biomass), we would have expected the same pattern on vegetated soils. However, we observed comparable root heavy metal concentrations for all three species on vegetated soils. Finally, the relative distribution of metallic elements in soils was quite different from those of roots and foliage, leading us to conclude that the foliar and root concentrations we measured were the result of plant processes and not of contamination by soil particles. We were, however, unable to determine what portion of the heavy metal we measured was contained in the root symplast vs. the apoplast and whether this varied with species or soil type. Nevertheless, sequestration in either of these compartments is a valid method for minimizing metal concentrations in foliage.

Elemental concentrations in foliage collected from Pinus sabiniana and Arctostaphylos glauca growing both in vegetated serpentine soils and in shrub islands within barren serpentine soil areas provided further evidence that plant species respond differently to serpentine soils but did not strongly implicate any specific factor(s) limiting plants on barren relative to vegetated soils. The greatest variation in elemental concentrations occurred between species. Soil type differences accounted for only a small proportion of the total variation in the data and were not always consistent between species (further evidence that 


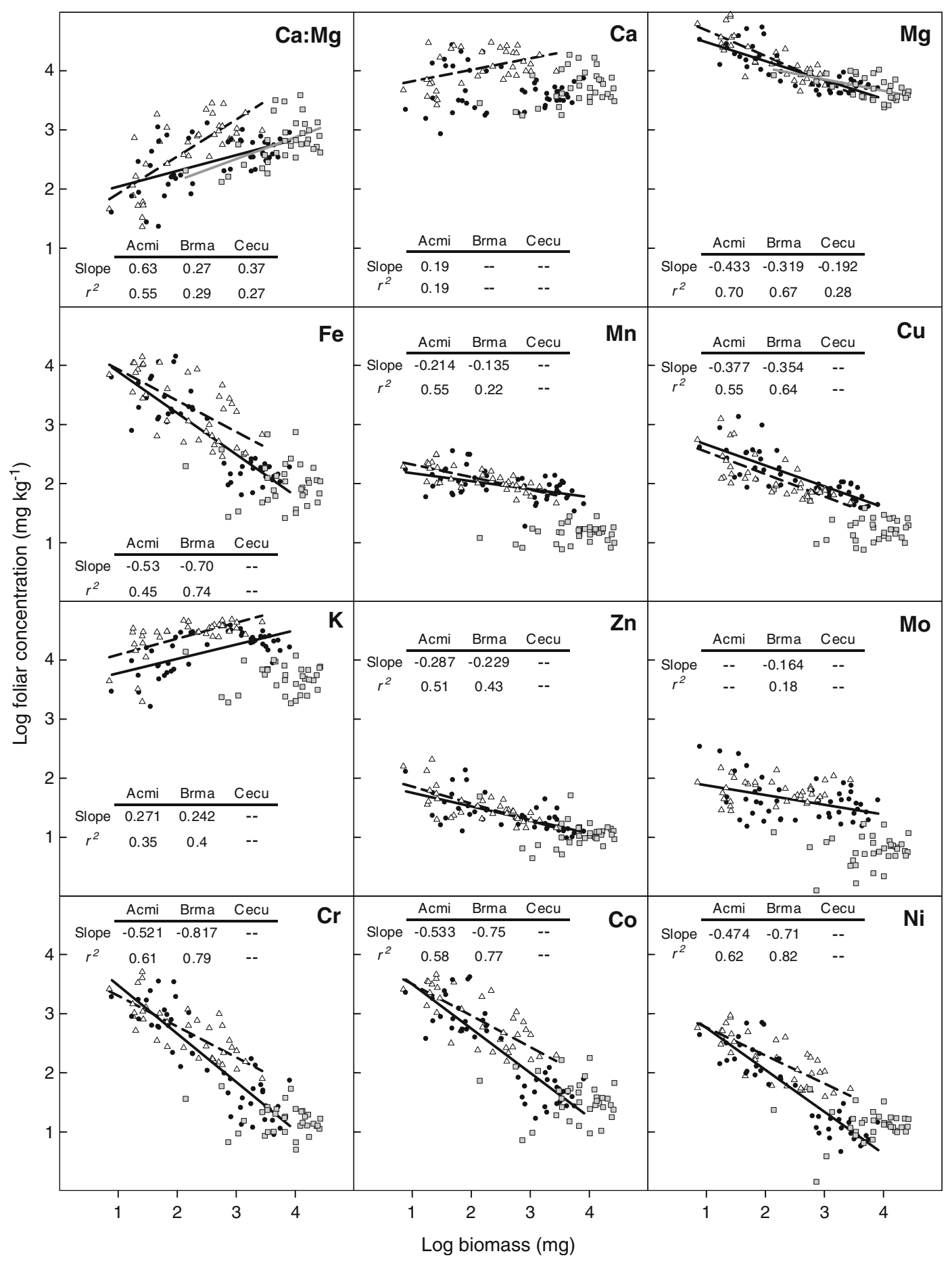

Fig. 7 Log $\log$ plots of foliar concentrations vs. biomass. Slopes are growth response coefficients sensu Poorter and van der Werf (1998). Open triangles and dashed lines are Achillea (Acmi), solid black circles and lines are Bromus (Brma), and gray squares and lines are Ceanothus (Cecu). Least squares fit lines, slopes, and $r^{2}$ values are provided for statistically significant correlations. All $P$-values $<0.0001$ except as follows: Ca: $\mathrm{Mg}$ Ceanothus $P=0.0018$; Ca Achillea $P=0.0084$; Mg Ceanothus $P=0.0014$; Mn Bromus $P=0.0009$; Mo Bromus $P=0.0033$ 
species responses to serpentine soils are vastly different). Inconsistencies between species generally occurred when there was a barren-vegetated difference for Arctostaphylos but not for Pinus, indicating that Pinus may be the more homeostatic of the two species. The strongest and most consistent differences between soil types were in $\mathrm{Fe}$ and Mo (higher concentrations in shrub-island foliage). It should also be emphasized, however, that it was not possible to measure foliar elements in plants growing on truly barren soils in the field (where no plants grew), and soil measurements showed many differences in shrub islands relative to truly barren soils. As such, it was also important to measure foliar concentrations in the plants we grew on soil collected in truly barren areas, as these may best reflect the chemical stresses such soils present.

Others have found ameliorative effects of $\mathrm{Ca}$ on metal toxicity (Gabbrielli \& Pandolfini 1984; Gabbrielli et al. 1990). Although we observed an increase in root length density and higher foliar and root $\mathrm{Ca}$ concentrations when $\mathrm{Ca}$ was added to barren soils, these were not accompanied by a biomass increase for Achillea or Bromus. Halstead (1968) also observed an increase in foliar $\mathrm{Ca}$ concentration without any accompanying growth increase in oats grown on a Guatemalan serpentine soil fertilized with $\mathrm{CaSO}_{4}$. Adding organic matter or $\mathrm{Ca}(\mathrm{OH})_{2}$ lowered foliar Ni concentrations and increased foliar $\mathrm{Ca}$ and total biomass, leading the author to conclude that $\mathrm{Ni}$ toxicity was the limiting factor for this plant in this soil and that it was overcome not by increasing $\mathrm{Ca}$ availability but by chelating $\mathrm{Ni}$, making it less available (organic matter) or raising soil $\mathrm{pH}$ and thus making Ni less soluble $\left(\mathrm{Ca}(\mathrm{OH})_{2}\right)$.

It is curious that none of our soil amendments were effective in significantly increasing growth for any species on vegetated serpentine soils. One possible explanation is continued metal toxicity on vegetated soils for Achillea and Bromus (see Fig. 7). Another possible explanation is that some other nutrient (such as $\mathrm{P}$ ) limited or co-limited growth on these soils. $\mathrm{P}$ levels on vegetated soils $(9.4 \mathrm{mg} / \mathrm{kg}$, bicarbonate extractable) were relatively low, though not uncharacteristically low for serpentine soils. It is also possible that the amounts of $\mathrm{N}, \mathrm{K}$, and $\mathrm{Ca}$ we added were not large relative to the pools of these elements already available on vegetated serpentine soils. Indeed, $\mathrm{N}$ levels in our fertilizer solutions were low relative to those measured in soil solution by Proctor et al. (1981), though $\mathrm{K}$ and Ca levels were somewhat higher and much higher than these respectively. Still, given the high degree of variation among serpentine soil solution nutrient contents $(28,66$, and 51 -fold differences in $\mathrm{N}, \mathrm{K}$, and $\mathrm{Ca}$ respectively for the seven soils measured by Proctor et al.), the most meaningful comparison would be with soil solutions obtained from vegetated New Idria soils.

The positive growth response of Ceanothus to added $\mathrm{N}$ on barrens is interesting in light of its ability to fix atmospheric $\mathrm{N}$ when growing with the bacterial symbiont Frankia. We did not observe root nodulation in any of our specimens growing on barren or vegetated soils. O'Dell et al. (2006) observed nodulation on pot-grown Ceanothus cuneatus and Ceanothus jepsonii grown in unfertilized serpentine soil and a lack of nodulation when NPKCa fertilizer was added. White (1967) found a near total absence of nodulation in Ceanothus cuneatus collected from four serpentine sites in the field, which he attributed to low NPK, low Mo, and toxic heavy metals.

Few studies have simultaneously addressed multiple hypotheses for serpentine infertility (i.e., low $\mathrm{Ca}: \mathrm{Mg}$, high heavy metals, low macronutrients), and even fewer have done so for multiple species/ functional types on more than one serpentine soil. Our results, taken together with the few other studies that simultaneously addressed multiple infertility hypotheses, suggest that on serpentine soils, herbaceous species may be more strongly affected by high heavy metal concentrations than woody species. Reports of metal toxicity in plants grown on serpentine soils or in soil solutions that approximate these soils' elemental concentrations are generally for herbaceous serpentine species (Nagy and Proctor 1997), non-serpentine ecotypes of herbaceous species (Proctor 1971; Woodell et al. 1975), or agricultural crop plants (Hunter and Vergnano 1952; Halstead 1968; Anderson et al. 1973). Studies of woody vegetation growing on serpentine soils that addressed both $\mathrm{Ca} / \mathrm{Mg}$ and heavy metal hypotheses of serpentine infertility have found significant positive relationships between growth or cover of woody species and soil (Alexander et al. 1989) or foliar (Koenigs et al. 1982) $\mathrm{Ca}$ or $\mathrm{Ca}: \mathrm{Mg}$ and not heavy metals. O'Dell et al. (2006) showed that the principal difference between serpentine and non-serpentine congeners of woody shrubs growing on a metalliferous California serpentine soil was in their ability to take up and translocate 
Ca to foliage and not their heavy metal resistance (serpentine and non-serpentine congeners equally sequestered heavy metals in roots). However, Kayama et al. (2005) showed higher Ni tolerance (possibly mediated through ectomycorrhizal fungi) in a common Japanese serpentine Picea (spruce) species than in two Picea species (one native, one introduced) that are generally excluded from serpentine soils. Examination of foliar elemental concentrations measured in native species on two British serpentine soils by Johnston and Proctor (1977) generally shows lower heavy metal concentrations ( $\mathrm{Fe}, \mathrm{Ni}, \mathrm{Co}$, and $\mathrm{Cr}$ ) and higher $\mathrm{Ca}: \mathrm{Mg}$ ratios in the woody plants (particularly Juniperus communis - common juniper) than in the herbaceous plants, which included both grasses and forbs. With the notable exception of $\mathrm{Mn}$, a similar pattern (generally lower heavy metals and higher $\mathrm{Ca}$ : $\mathrm{Mg}$ in woody plant foliage) was observed for 12 herbaceous and 5 woody species growing on a serpentine soil in Maine, USA (Pope et al. 2010).

While our study identified clear differences in chemistry between barren and vegetated soils that affect plant growth and likely help maintain the barren-vegetated landscape pattern, the results also provide some clues as to the initial causes of this landscape pattern (Fig. 8). Our study leaves only two possible initial causes - either the explanation for the difference between the two soil types lies with 1) lack of soil development on barrens (perhaps due to instability caused by steeper slopes and/or softer, more erodible parent material, as hypothesized by Coleman 1996 and Kruckeberg 1999) or 2) there are differences in parent material that influence soil chemical properties (e.g., Ca-bearing accessory minerals on vegetated soils - see McGahan et al. 2008) (upper panel Fig. 8). Indeed, $\mathrm{Ca}: \mathrm{Mg}$ ratios of shrubisland soils more closely matched those of barren than vegetated soils, suggesting that this difference may be related to differing parent material properties (lower panels Fig. 8). This could be verified by analyses of underlying parent material. In contrast to this, shrub island soils were generally intermediate between barren and vegetated soils (total N, Ca, Mn) or more similar to vegetated soils (CEC, organic matter, $\mathrm{Mg}$, $\mathrm{K}, \mathrm{Fe}, \mathrm{Ni}, \mathrm{Cr}$ ) for most properties for which significant differences were measured, indicating that plants may have influenced these properties (arrows Fig. 8). In shrub-island and vegetated soils, added organic matter and facilitated weathering of clay

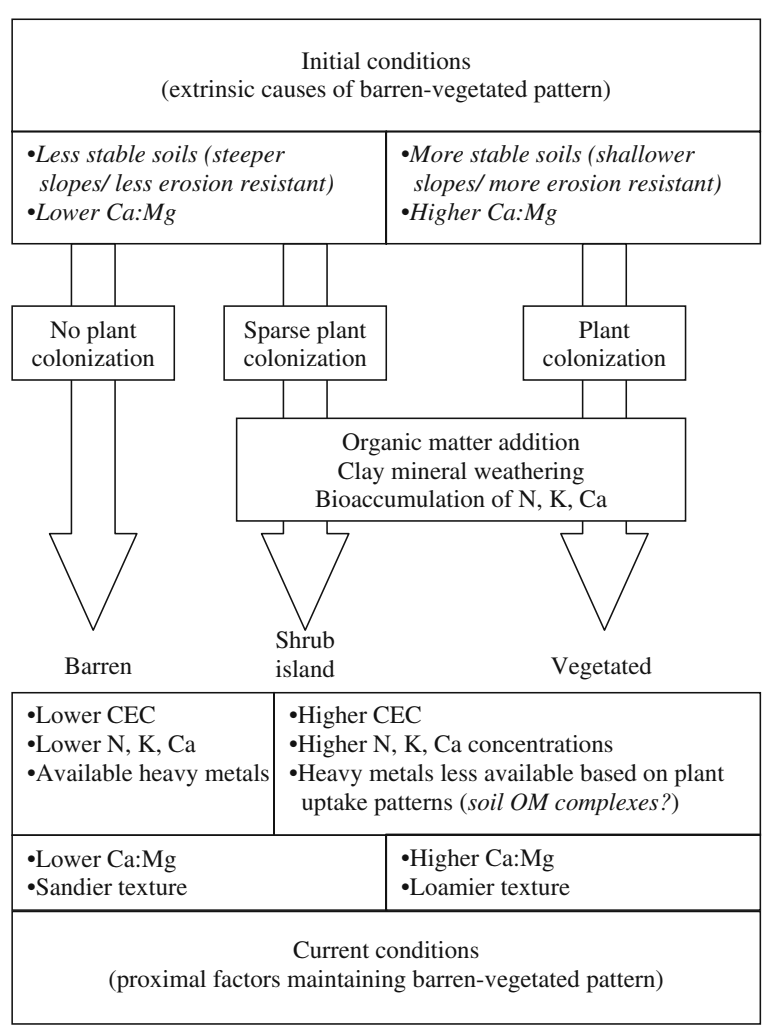

Fig. 8 Diagram depicting extrinsic factors causing the barrenvegetated pattern on the New Idria serpentine mass and proximal causes maintaining the pattern. Factors in italics are hypotheses which can be neither supported nor refuted by the current study

minerals would increase CEC leading to greater retention and bioaccumulation of $\mathrm{Ca}$ and $\mathrm{K}$. N also accumulates selectively under the long-lived shrubs in shrub islands and in vegetated serpentine soils. In summary, some of the proximal stresses maintaining the barren-vegetated pattern (e.g., differences in heavy metal availability based on plant uptake in our experiments, $\mathrm{N}$ concentrations) are likely feedbacks caused by differential soil development due to differences in plant colonization. In contrast, the extrinsic causes of differential colonization and hence differential soil development appear to be 1) differences in parent material stability and/or 2) differences in parent material Ca:Mg (Fig. 8). Future studies should assess mechanisms affecting heavy metal availability, parent material characteristics, and bioaccumulation rates and patterns.

Our results have some important implications for restoration of vegetation or establishing shrub and tree islands on serpentine soil areas degraded by logging, 
mining, and off-highway vehicle use. Perhaps the most important of these is the need to plant metaltolerant species first on barrens. Once plants have become established and soil organic matter increases, metal availability may be reduced sufficiently for less metal-tolerant species. Alternatively, soil amendments that ameliorate metal toxicity may allow less metal tolerant plants to become established. One interesting possibility would be to use soil collected from vegetated areas, if such areas need to be cleared or disturbed for any reason. Organic amendments such as peat moss or compost have also been shown to ameliorate metal toxicity (Halstead 1968; Fernandez et al. 1999; O'Dell and Claassen 2006). Indeed, some of the most promising results to date in serpentine restoration/revegetation have been obtained using organic amendments (O'Dell and Claassen 2006). Although care should always be taken to minimize the distribution of weed seeds, it appears that the weed of greatest concern for this area, Bromus madritensis ssp. rubens, is excluded from barren areas by soil chemical properties, and thus the spread of this species is of greater concern for recently disturbed vegetated areas, where it is not excluded by soil chemistry. Our results indicate that adding mineral $\mathrm{N}$ or Ca to barrens might assist at least one metal tolerant species (Ceanothus cuneatus) to establish more quickly. If this is attempted in the field, it should be done incrementally at a small scale and monitored well, as $\mathrm{Ca}$ did increase Bromus root growth on barren soils, and because $\mathrm{N}$ fertilization has favored non-natives over natives in some cases in previous studies (e.g., Huenneke et al. 1990; Going et al. 2009). In addition, Harrison et al. (2006) found that predictors of exotic species cover on serpentine soils throughout California included higher soil $\mathrm{Ca}: \mathrm{Mg}$.

The fact that the factors maintaining the New Idria barren-vegetated pattern appear to be specific to plant species or functional groups (i.e., low $\mathrm{Ca} /$ high $\mathrm{Mg}$ for all species, low $\mathrm{N}$ for some, high heavy metals for others) emphasizes a point made by Alexander et al. (2007): the relative importance of the various facets of the serpentine syndrome in plant growth limitation are specific not only to the soil, but also to the plant species or functional group in question. This more flexible view of the serpentine syndrome reconciles the disparate results of many researchers and eschews generalizations applied to all serpentine plants and soils based on the results of one or a few studies.
Acknowledgements Support for this research was provided by the University of California Toxic Substances Research and Teaching Program (TSR\&TP) through the Atmospheric Aerosols and Health Lead Campus Program (aah.ucdavis.edu), the United Stated Bureau of Land Management, the Santa Clara Valley Chapter of the California Native Plant Society, JastroShields, and the California Agricultural Experiment Station. We are grateful to Phoebe Gordon, Emily Tozzi, Prashanth Arulsakaran, Wesley Collatz, Lisa Auchincloss, Hsien Easlon, and Deirdre Levine for greenhouse and laboratory assistance. We also thank Julie Bower, Tad Doane, and Donald McGahan for technical support, Valerie Eviner for advice and manuscript review, and Susan Harrison and Nishi Rajakaruna for manuscript review.

Open Access This article is distributed under the terms of the Creative Commons Attribution Noncommercial License which permits any noncommercial use, distribution, and reproduction in any medium, provided the original author(s) and source are credited.

\section{References}

Alexander EB, Adamson C, Zinke PJ, Graham RC (1989) Soils and conifer forest productivity on serpentinized peridotite of the Trinity Ophiolite, California. Soil Sci 148:412-423

Alexander EB, Coleman RG, Keeler-Wolf T, Harrison SP (2007) Serpentine geoecology of Western North America: geology, soils, and vegetation. Oxford University Press, New York

Anderson AJ, Meyer DR, Mayer FK (1973) Heavy-metal toxicities - levels of nickel, cobalt, and chromium in soil and plants associated with visual symptoms and variation in growth of an oat crop. Aust J Agric Res 24:557-571

Chiarucci A, Maccherini S, Bonini I, De Dominicis V (1999) Effects of nutrient addition on community productivity and structure of serpentine vegetation. Plant Biol 1:121-126

Coleman RG (1986) Field trip guide book to New Idria area, California. 14th general meeting of the International Mineralogical Association. July, 1986. Stanford University, Palo Alto

Coleman RG (1996) New Idria serpentinite: a land management dilemma. Environ Eng Geosci 2:9-22

Emery DE (1988) Seed propagation of native California plants. Santa Barbara Botanic Garden, Santa Barbara

Fernandez S, Seoane S, Merino A (1999) Plant heavy metal concentrations and soil biological properties in agricultural serpentine soils. Commun Soil Sci Plant Anal 30:1867-1884

Gabbrielli R, Pandolfini T (1984) Effect of $\mathrm{Mg}_{-}{ }^{2+}$ and $\mathrm{Ca}^{2+}$ on the response to nickel toxicity in a serpentine endemic and nickel-accumulating species. Physiol Plant 62:540-544

Gabbrielli R, Pandolfini T, Vergnano O, Palandri MR (1990) Comparison of two serpentine species with different nickel tolerance strategies. Plant Soil 122:271-277

Going BM, Hillerislambers J, Levine JM (2009) Abiotic and biotic resistance to grass invasion in serpentine annual plant communities. Oecologia 159:839-847 
Grace JB, Safford HD, Harrison S (2007) Large-scale causes of variation in the serpentine vegetation of California. Plant Soil 293:121-132

Hall JL, Williams LE (2003) Transition metal transporters in plants. J Exp Bot 54:2601-2613

Halstead RL (1968) Effect of different amendments on yield and composition of oats grown on a soil derived from serpentine material. Can J Soil Sci 48:301-305

Harrison S, Grace JB, Davies KF, Safford HD, Viers JH (2006) Invasion in a diversity hotspot: Exotic cover and native richness in the Californian serpentine flora. Ecology 87:695-703

Huenneke LF, Hamburg SP, Koide R, Mooney HA, Vitousek PM (1990) Effects of soil resources on plant invasion and community structure in Californian serpentine grassland. Ecology 71:478-491

Hunter JG, Vergnano O (1952) Nickel toxicity in plants. Ann Appl Biol 39:279-284

James JJ, Tiller RL, Richards JH (2005) Multiple resources limit plant growth and function in a saline-alkaline desert community. J Ecol 93:113-126

Johnston WR, Proctor J (1977) Metal concentrations in plants and soils from two British serpentine sites. Plant Soil 46:275-278

Kayama M, Quoreshi AM, Uemura S, Koike T (2005) Differences in growth characteristics and dynamics of elements absorbed in seedlings of three spruce species raised on serpentine soil in northern Japan. Ann Bot 95:661-672

Koenigs RL, Williams WA, Jones MB, Wallace A (1982) Factors affecting vegetation on a serpentine soil II chemical-composition of foliage and soil. Hilgardia 50:15-26

Koide RT, Mooney HA (1987) Revegetation of serpentine substrates - response to phosphate application. Environ Manage 11:563-567

Kruckeberg AR (1951) Intraspecific variability in the response of certain native plant species to serpentine soil. Am J Bot 38:408-419

Kruckeberg AR (1984) California Serpentines: Flora, vegetation, geology, soils and management problems. University of California Press, Berkeley

Kruckeberg AR (1999) Serpentine barrens of Western North America. In: Anderson RC, Fralish JS and Baskin JM (eds) Savannas, barrens, and rock outcrop plant communities of North America. Cambridge University Press, pp. 309-321

Lyon GL, Peterson PJ, Brooks RR, Butler GW (1971) Calcium, magnesium and trace elements in a New Zealand serpentine flora. J Ecol 59:421-429

McGahan DG, Southard RJ, Claassen VP (2008) Tectonic inclusions in serpentinite landscapes contribute plant nutrient calcium. Soil Sci Soc Am J 72:838-847

McGahan DG, Southard RJ, Claassen VP (2009) Plantavailable calcium varies widely in soils on serpentinite landscapes. Soil Sci Soc Am J 73:2087-2095

Nagy L, Proctor J (1997) Plant growth and reproduction on a toxic Alpine ultramafic soil: adaptation to nutrient limitation. New Phytol 137:267-274

O'Dell RE, Rajakaruna N (2011) Intraspecific variation, adaptation, and evolution. In: Harrison SP, Rajakaruna N (eds.) Serpentine: Evolution and ecology in a model system. University of California Press, pp. 97-137
O'Dell RE, Claassen VP (2006) Serpentine and nonserpentine Achillea millefolium accessions differ in serpentine substrate tolerance and response to organic and inorganic amendments. Plant Soil 279:253-269

O'Dell RE, Claassen VP (2009) Serpentine revegetation: a review. Northeast Nat 16:253-271

O'Dell RE, James JJ, Richards JH (2006) Congeneric serpentine and nonserpentine shrubs differ more in leaf $\mathrm{Ca}: \mathrm{Mg}$ than in tolerance of low N, low P, or heavy metals. Plant Soil 280:49-64

Palmer CM, Guerinot ML (2009) Facing the challenges of $\mathrm{Cu}, \mathrm{Fe}$ and $\mathrm{Zn}$ homeostasis in plants. Nat Chem Biol 5:333-340

Poorter $\mathrm{H}$, van der Werf A (1998) Is inherent variation in $R G R$ determined by $L A R$ at low irradiance and by NAR at high irradiance? A review of herbaceous species. In: Lambers $\mathrm{H}$, Poorter H, Van Vuuren MMI (eds) Inherent variation in plant growth: physiological mechanisms and ecological consequences. Backhuys, Leiden, pp 309-336

Pope T, Harris TB, Rajakaruna N (2010) Vascular plants of adjacent serpentine and granite outcrops on the Deer Isles, Maine, USA. Rhodora 112:105-141

Proctor J (1971) Plant ecology of serpentine II plant response to serpentine soils. J Ecol 59:397-410

Proctor J, Woodell SR (1975) The ecology of serpentine soil. Adv Ecol Res 9:256-365

Proctor J, Johnston WR, Cottam DA, Wilson AB (1981) Field capacity water extracts from serpentine soils. Nature 294:245-248

Rajakaruna N, Bohm BA (1999) The edaphic factor and patterns of variation in Lasthenia californica (Asteraceae). Am J Bot 86:1576-1596

Rice WR (1990) A consensus combined $P$-value test and the family-wide significance of component tests. Biometrics 46:303-308

Robinson BH, Brooks RR, Clothier BE (1999) Soil amendments affecting nickel and cobalt uptake by Berkheya coddii: potential use for phytomining and phytoremediation. Ann Bot 84:689-694

Safford HD, Viers JH, Harrison SP (2005) Serpentine endemism in the California flora: a database of serpentine affinity. Madrono 52:222-257

Sah RN, Miller RO (1992) Spontaneous reaction for acid dissolution of biological tissues in closed vessels. Anal Chem 64:230-233

Shewry PR, Peterson PJ (1976) Distribution of chromium and nickel in plants and soil from serpentine and other sites. J Ecol 64:195-212

Soil Survey Staff (2010) National Soil Survey Characterization Data, Soil Survey Laboratory, National Soil Survey Center USDANRCS - Lincoln, NE. http://ssldata.nrcs.usda.gov/rptExecute. asp? $\mathrm{p}=40155 \& \mathrm{p}=40156 \& \mathrm{r}=1 \& \mathrm{~g}=$ on $\&$ submit $1=$ Get + Report. Accessed 07/23/2010

White CD (1967) Absence of nodule formation on Ceanothus cuneatus in serpentine soils. Nature 215:875

Woodell SRJ, Mooney HA, Lewis H (1975) Adaptation to serpentine soils in California of annual species LinanthusAndrosaceus (Polemoniaceae). Bull Torrey Bot Club 102:232-238

Yang XH, Brooks RR, Jaffre T, Lee J (1985) Elemental levels and relationships in the Flacourtiaceae of New Caledonia and their significance for the evaluation of the serpentine problem. Plant Soil 87:281-291 